\title{
Improving Libido and Sperm Quality of Bali Bulls by Supplementation of Moringa oleifera Leaves
}

\author{
N. A. Syarifuddin ${ }^{a *}$, A. L. Toleng ${ }^{b}$, D. P. Rahardja ${ }^{b}$, Ismartoyo ${ }^{c}$, \& M. Yusuf ${ }^{b}$ \\ aDoctoral Program of Agricultural Sciences, the Graduate School, Hasanuddin University \\ ${ }^{b}$ Department of Animal Production, Faculty of Animal Sciences, Hasanuddin University \\ 'Department of Animal Nutrition, Faculty of Animal Sciences, Hasanuddin University \\ Jalan Perintis Kemerdekaan Km 10, Kampus Tamalanrea, Makassar 90245, Indonesia \\ (Received 20-04-2017; Reviewed 30-05-2017; Accepted 21-06-2017)
}

\begin{abstract}
Moringa oleifera (Moringa) leaves contain high levels of nutrient that can be utilized as a feed supplement to increase libido and semen quality. This study was aimed to evaluate the effect of Moringa leaves supplementation on libido and sperm quality of Bali bulls. This study used two-sample t-test on four Bali bulls were kept under individual pens for two periods of eight weeks. During the first period (control), the experimental Bali bulls were fed concentrates ( $1 \%$ of body weight) and rice straw ad libitum. During the second period, the experimental Bali bulls were fed similar to the first period with an additional of Moringa leaves $15 \%$ of the weight of the concentrate (treatments). Libido and sperm quality were measured twice a week. Plasma samples were taken three times a day (06:00, 14:00, and 22:00h) on the last day of each period. Plasma testosterone concentrations were analyzed by using ELISA techniques. Variables measured were compared using paired student's t-test. Supplementation of Moringa leaves increased testosterone levels $(\mathrm{P}<0.05)(4.57$ vs $4.79,0.45$ vs 4.78 , and 2.35 vs $5.63 \mathrm{ng}$ / $\mathrm{mL}$, respectively during $06.00 ; 14.00$; and $22.00 \mathrm{~h})$, increased libido $(\mathrm{P}<0.05)(7.20 \pm 1.49$ vs $3.49 \pm 0.40 \mathrm{~min})$, and increased both the total motility $(P<0.05)(63.99 \pm 3.37 \%$ vs $84.96 \pm 3.09 \%)$ and the progressive motility $(\mathrm{P}<0.05)(52.77 \pm 1.76 \%$ vs $67.03 \pm 3.74 \%)$ of sperm. Supplementation of Moringa leaves also increased $(\mathrm{P}<0.05)$ the velocity and the amplitude and decreased $(\mathrm{P}<0.05)$ the linearity of sperm. It can be concluded that the supplementation of Moringa leaves could increase plasma testosterone concentrations, libido, and sperm motility of Bali bulls.
\end{abstract}

Keywords: libido, semen quality, Bali bulls, Moringa oleifera, rice straw

\section{ABSTRAK}

Daun kelor mengandung nutrien yang tinggi sehingga dapat dimanfaatkan sebagai bahan pakan tambahan untuk meningkatkan libido dan kualitas semen. Penelitian ini bertujuan untuk mengevaluasi pengaruh suplementasi daun kelor terhadap libido dan kualitas sperma pejantan sapi Bali. Penelitian ini menggunakan uji perbandingan dua nilai tengah terhadap 4 ekor pejantan sapi bali yang dipelihara secara intensif pada kandang individual selama 2 periode, masing-masing 8 minggu. Pada periode pertama (kontrol), sapi pejantan diberi pakan konsentrat $1 \%$ bobot badan dan jerami padi secara ad libitum. Pada periode kedua, sapi pejantan tersebut diberi pakan yang sama dengan pada periode pertama dengan tambahan daun kelor 15\% dari bobot konsentrat (perlakuan). Libido dan kualitas sperma diukur 2 kali seminggu. Sampel plasma diambil 3 kali sehari (pukul 06.00, 14.00, dan 22.00) pada hari terakhir setiap periode. Konsentrasi testosteron dalam plasma dianalisis dengan menggunakan teknik ELISA. Peubah yang diukur dibandingkan dengan menggunakan uji $t$ berpasangan (paired student's $t$-test). Suplementasi daun kelor meningkatkan kadar hormon testosteron dalam plasma $(P<0,05)(4,57$ vs 4,79 ; 0,45 vs 4,78 ; dan 2,35 vs $5,63 \mathrm{ng} / \mathrm{mL}$ ), masing-masing pada pukul $06.00,14.00$, dan 22.00), meningkatkan libido $(\mathrm{P}<0.05)(7,20 \pm 1,49$ vs 3,49 $\pm 0,40$ menit $)$, dan meningkatkan motilitas total $(\mathrm{P}<0.05)(63,99 \pm 3,37 \%$ vs $84,96 \pm 3,09 \%)$ dan motilitas progresif $(\mathrm{P}<0.05)(52,77 \pm 1,76 \%$ vs $67,03 \pm 3,74 \%)$ sperma pejantan sapi bali. Suplementasi daun kelor juga meningkatkan $(P<0,05)$ kecepatan dan amplitudo, serta menurunkan $(\mathrm{P}<0,05)$ linearitas sperma. Dapat disimpulkan bahwa suplementasi daun kelor dapat meningkatkan kadar hormon testosteron dalam plasma, libido, dan motilitas sperma pejantan sapi bali.

Kata kunci: libido, kualitas air mani, pejantan sapi Bali, Moringa oleifera, jerami padi

*Corresponding author:

E-mail: nursyam_pronak@yahoo.com 


\section{INTRODUCTION}

Low libido and poor semen quality are factors affecting the reproductive performance of bulls. The bulls to be used for natural mating and as sources of semen for artificial insemination should have good libidos and semen qualities, because these factors will affect the reproductive efficiency of cows. Subfertile bulls like low libido and poor semen quality will delay conception, prolong the calving season, reduce calf weaning weights, and increase the numbers of cows culled, thereby resulting in economic losses and threatening the sustainability of a livestock operation (Kastelic, 2013).

The sexual behavior (libido and mounting capacity) of bulls depends on social interaction, which is affected by genetic, environmental, nutritional, and hormonal factors, as well as by sensorial acuity, age, and experience (Menegassi et al., 2011). The semen quality of a bull is influenced by the nutritional factor (Martin et al., 2010), age, season (Bhakat et al., 2011), and breed (Lemma \& Shemsu, 2015). The nutrition status of a bull controls sperm production, the secretion of gonadotropin, and sexual development. The capacity of testes of an adult male animal to produce sperm and testosterone is influenced by the ability of the seminiferous tubules and the Leydig cells or interstitial cells under the stimulation of Follicle Stimulating Hormone (FSH) and Luteinizing Hormone (LH) (Martin et al., 2010).

The process of spermatogenesis to produce semen of a good quality requires amino acids methionine, cysteine (Young et al., 2008), and arginine (Wu et al., 2009), a fatty acid $\alpha$-linoleic, vitamin A, C, and $\mathrm{E}$ as well as $\mathrm{Zn}$ and Se (Cheah \& Yang, 2011). Zn plays a fundamental role in the production of many sex hormones including testosterone and Gonadotropin Releasing Hormone $(\mathrm{GnRH})$. Zn stimulates Leydig cells of the testis to produce testosterone. It is localized in Golgi complex or secretory vesicles of interstitiotrophs, folliculotrophs, and lactotrophs of the pituitary gland. This element plays an important role in the production and secretion of $\mathrm{FSH}$, $\mathrm{LH}$, and prolactin that eventually regulate testosterone production (Roy et al., 2013). The bio-constituents contained in herbs that are responsible for enhancing sexual activity and spermatogenesis include saponin, alkaloid, flavonoid, ferulic acid, and chlorogenic acid (Chauhan et al., 2014). One of the plants that contain all of these compounds is Moringa oleifera leaves.

M. oleifera is a tree plant, found in the tropical countries, that is potential to be used for animal feed. Moringa leaves is a good alternative for fodder crops, especially in the dry season when no fodder is available (Nouman at al., 2013). The biomass production is 4.2-8.2 tons DM/ha and is a good alternative for substituting commercial ration for livestock (Nouman at al., 2014) and a good feed additive (Fitri et al., 2015). The leaves of this plant are rich in nutritive values. The values of amino acids, fatty acids, minerals, and vitamin profiles reflect a desirable nutritional balance. The levels of crude protein content is $30.29 \%$, fat is $6.50 \%$, ash is $7.64 \%$, calcium is $3.65 \%$, phoshorus is $0.3 \%$, neutral detergent fibre is $11.4 \%$, acid detergent fibre is $8.49 \%$, acid detergent lignin is $1.80 \%$, acid detergent cellulose is $4.01 \%, \mathrm{Zn}$ is $31.03 \mathrm{mg} / \mathrm{kg}$ (Moyo et al., 2011), saponin is $80 \mathrm{~g} / \mathrm{kg}$ (Ferriera et al., 2008), phenol is $8 \mu \mathrm{g} / \mathrm{mL}$, flavonoids is $27 \mathrm{ug} / \mathrm{mL}$ (Rajanandh \& Kavitha, 2010), and alkaloid is $0.07 \%$ (Madukwe et al., 2013), ferulic acid is $46.8 \mathrm{mg} / \mathrm{g}$, and chlorogenic acid is $18.0 \mathrm{mg} / \mathrm{g}$ (Fitri et al., 2015). In addition, Moringa leaves contain tannin $21 \mathrm{~g} / \mathrm{kg}$ $\mathrm{DM}$ and pytat $21 \mathrm{~g} / \mathrm{kg} \mathrm{DM}$ that can be ignored as antinutrients for ruminants, and do not contain trypsin and amylase inhibitors, lectins, cyanogenic glycosides, and glucosinolates (Ferreira et al., 2008).

Various studies have been carried out by utilizing Moringa leaves as feed material, but for the purpose of increasing libido and semen quality is still limited. The results of research of Abu et al. (2013) show that Moringa leaves meal (MOLM) had no adverse effect on the testicular morphometry and epididymal sperm quality of rabbit bucks at inclusion level of up to $15 \%$. It is suggested that $M$. oleifera leaves can be used in rabbit diets. Raji \& Njidda (2014) showed that supplementation with Moringa leaves at $50 \%$ level of inclusion could enhance the gonadal and extragonadal sperm reserves in Red Sokoto goats. Therefore, this study will use Moringa leaves as feed dietary supplement to increase libidos, serum testosterone concentrations, and sperm motilities in Bali bulls.

\section{MATERIALS AND METHODS}

\section{Animals, Experimental Design, and Diet}

Animals. This study used 4 Bali bulls with 5 years old age and average body weight of $262 \pm 40.40 \mathrm{~kg}$. The experimental bulls were intensively kept under individual animal house.

Experimental design. This study was divided into 2 periods and each period was conducted for 8 weeks. The first 2 weeks of each period were the adaptation phase. At the first period, the experimental bulls were fed with concentrates (1\% of body weight) and rice straw ad libitum (control). Furthermore, at the second period, they were fed diet similar to that used in the first period with an additional of Moringa leaves 15\% of the weight of the concentrate (treatments). This study used two-sample t-test to compare each parameter in both periods.

Measurements of libido and semen quality were carried out simultaneously twice a week. Libido was measured by calculating the time required for the bulls from approaching the teaser until they ejaculated. Before semen collection, the false mounting was conducted twice.

Semen was collected by using an artificial vagina. The collected semen was handled according to the procedures of Susilawati (2011). The volume, color, $\mathrm{pH}$, and, viscosity, as well as a mass movement, were recorded. Evaluation of semen quality in the form of the sperm concentration, motility, curvilinear velocity (VCL), straight line velocity (VSL), average path velocity (VAP), linearity (LIN), amplitude of lateral head movement $(\mathrm{ALH})$, and beat cross frequency (BCF) were done by using Computer Assisted Semen Analyzer (CASA) with Sperm Vision ${ }^{\mathrm{TM}}$ Version 3.7.5 software.

Blood samples were taken from the jugular vein using vacutainer tubes at the last day for both periods of 
study. The samples were collected 3 times a day (06:00, 14:00, and 22:00 h). The plasma samples were stored at $-20^{\circ} \mathrm{C}$ until the hormonal assay. Testosterone was analyzed by using ELISA technique in accordance with the procedures of DRG International, Inc., USA (2009).

Diet and feeding. During the experimental period, the experimental bulls were fed with rice straw ad libitum and supplemented with concentrate $1 \%$ of their body weight. The experimental bulls were given rations according to the standard nutritional needs for bulls by Nutrient Requirements of Beef Cattle (2000).

Table 1. The composition of feed concentrate

\begin{tabular}{lc}
\hline Feed ingredients & $\%$ \\
\hline Rice bran & 25 \\
Cocoa pod meal & 12 \\
Shrimp heads meal & 15 \\
Soybean meal waste/ tofu waste & 40 \\
Salt & 5 \\
Mineral mix for beef & 3 \\
Total & 100 \\
\hline
\end{tabular}

Table 2. Nutrient composition of feed concentrate, Moringa leaves, and rice straw (as \% DM)

\begin{tabular}{lccc}
\hline \multicolumn{1}{c}{ Nutrient $(\%)$} & $\begin{array}{c}\text { Feed } \\
\text { concentrate }\end{array}$ & $\begin{array}{c}\text { Moringa } \\
\text { leaves }\end{array}$ & Rice straw \\
\hline Dry matter & 63.62 & 88.16 & 89.86 \\
Crude protein & 13.47 & 25.70 & 4.12 \\
Ether extract & 5.64 & 10.20 & 1.35 \\
Crude fiber & 21.69 & 9.48 & 33.25 \\
Nitrogen free extract & 34.76 & 41.56 & 44.89 \\
Ash & 24.76 & 13.06 & 16.39 \\
Ca & 2.53 & 3.34 & 0.46 \\
P & 0.67 & 0.39 & 0.10 \\
\hline
\end{tabular}

Note: Analyzed by Laboratory of Nutrition and Animal Feedstuff, Faculty of Animal Sciences, Hasanuddin University.

Table 3. Composition of experimental ration (\%)

\begin{tabular}{lcc}
\hline & Control & Treatment \\
\hline Ingredient (\%) & & \\
Rice straw & 88 & 85 \\
Concentrate & 12 & 12 \\
$\quad$ Moringa leaves & 0 & 3 \\
Nutrient composistion (\%) & & \\
Dry matter & 85.64 & 85.40 \\
Crude protein & 5.24 & 5.87 \\
Ether extract & 1.87 & 2.13 \\
Crude fiber & 31.86 & 31.16 \\
Nitrogen free extract & 43.67 & 43.52 \\
Ash & 17.4 & 17.36 \\
Ca & 0.71 & 0.80 \\
P & 0.17 & 0.18 \\
\hline
\end{tabular}

Composition of concentrate and chemical composition of concentrate, Moringa leaves, and rice straw are presented in Table 1 and Table 2. Composition of experimental ration is presented in Table 3 .

\section{Statistical Analysis}

Data (sperm concentration and motility) were reported as mean and standard error of mean analyzed using the paired student's t-test with SPSS ${ }^{\circledR}$ Version 22 software.

\section{RESULTS}

\section{Dry Matter and Nutrients Consumptions}

The dry matter and nutrients consumptions of experimental Bali bulls are presented in Table 4. The dry matter and TDN consumptions of experimental Bali bulls supplemented with Moringa leaves were not statistically different compared to the control Bali bulls without Moringa leaves supplementation. However, the crude protein, $\mathrm{Ca}$, and $\mathrm{P}$ minerals consumptions were significantly higher $(\mathrm{P}<0.05)$ in the experimental Bali bulls supplemented with Moringa leaves compared to control.

\section{Testosterone Levels and Libido}

Diurnal changes of plasma testosterone concentrations and libido of the experimental Bali bulls are presented in Figures 1 and 2. Plasma testosterone concentrations in the experimental Bali bulls supplemented with Moringa leaves were higher in the morning, at noon, and in the evening compared to the control group. Libido of the experimental bulls supplemented with Moringa leaves was significantly higher $(\mathrm{P}<0.05)$ compared the control group.

\section{Semen Quality and Characteristics of Sperm Motility of Bali Bulls}

Semen quality (sperm concentration and motility) and characteristics of sperm motilities in experimental Bali bulls are presented in Table 5. The concentrations of sperm of experimental Bali bulls supplemented with Moringa leaves were not statistically different compared

Table 4. Dry matter and nutrients consumptions of Bali bulls without and with supplementation of Moringa leaves ( $\mathrm{kg} /$ day)

\begin{tabular}{lccc}
\hline Intake & Control & Treatment & Requirement $^{1}$ \\
\hline Dry matter & $13.86 \pm 0.271$ & $13.29 \pm 0.271$ & 6.30 \\
Crude protein & $0.72 \pm 0.011^{\mathrm{a}}$ & $0.78 \pm 0.012^{\mathrm{b}}$ & 0.59 \\
$\mathrm{TDN}$ & $6.03 \pm 0.12$ & $5.79 \pm 0.12$ & 3.67 \\
$\mathrm{Ca}$ & $0.098 \pm 0.002^{\mathrm{a}}$ & $0.107 \pm 0.002^{\mathrm{b}}$ & 0.015 \\
$\mathrm{P}$ & $0.023 \pm 0.0003^{\mathrm{a}}$ & $0.024 \pm 0.0003^{\mathrm{b}}$ & 0.009 \\
\hline
\end{tabular}

Note: Means in the same row with different superscripts differ significantly $(\mathrm{P}<0.05) .{ }^{1}$ Adapted from NRC (2000), Nutrient Requirements of Beef Cattle, $7^{\text {th }}$ revised edition. 
to the control Bali bulls without Moringa leaves supplementation. The total and progressive motilities of sperm were significantly higher $(\mathrm{P}<0.05)$ in the experimental Bali bulls supplemented with Moringa leaves compared to the control Bali bull without Moringa leaves supplementation.

The velocities of sperm in a minute on the trajectory curve (VCL), on a straight path (VSL), and the average trajectory of the plot (VAP), were significantly faster $(\mathrm{P}<0.05)$ in the experimental Bali bulls supplemented with Moringa leaves compared to the control groups. The percentage of LIN was significantly lower $(\mathrm{P}<0.05)$ in the experimental Bali bulls supplemented with Moringa leaves compared to the control groups. Distance lateral movement of the sperm head at each average plot $(\mathrm{ALH})$ was significantly higher $(\mathrm{P}<0.05)$ in the experimental Bali bulls supplemented with Moringa leaves compared to the control Bali bulls without Moringa leaves supplementation. However, the frequency of sperm movement (BCF) or the average flow linear curve average sperm pass through the plot was similar in experimental Bali bulls with or without Moringa leaves supplementation.

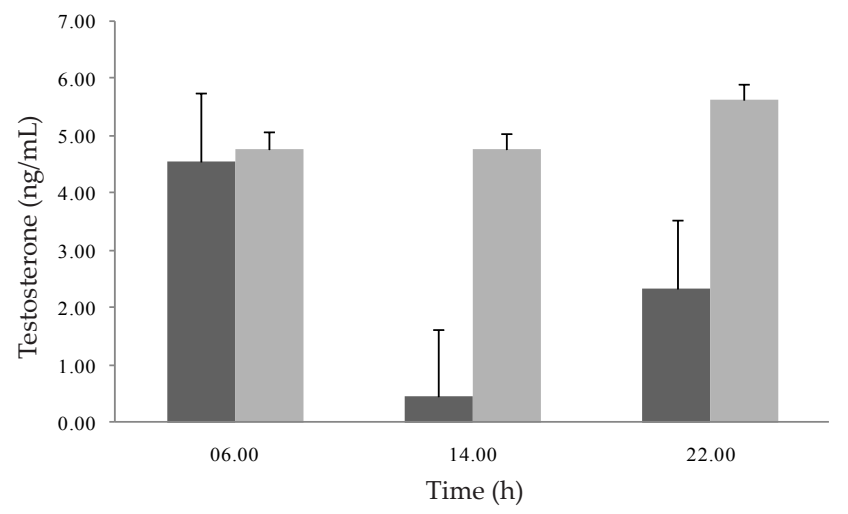

Figure 1. Diurnal changes of plasma testosterone concentrations in Bali bulls without (control; dark bar) and with (treatment; pale bar) supplementation of Moringa leaves.

\section{DISCUSSION}

The results of this study indicated that supplementation of Bali bulls with Moringa leaves increased plasma testosterone concentrations, libido, and sperm motility. During the treatment period (period 2), the plasma testosterone concentrations were higher all the day long, the intervals between approaching the teaser until ejaculation were shorter, and the total and progressive motilities were higher compared to those during the untreated period.

The higher plasma concentrations of testosterone during the Moringa leaves supplementation was in accordance with the study in rats by Prabsattroo et al. (2015) and Dafaalla et al. (2016). They reported that Moringa leaves supplementation significantly increased serum testosterone in the rat. The treatment of Moringa leaves could also increase Leydig cells (Prabsattroo et al., 2015) and the levels of FSH and LH (Dafaalla et al., 2016). The testosterone synthesis performed by Leydig cells in the testes depends on the adequacy of $\mathrm{Zn}$ in the diet (Roy et al., 2013). Further, Zn minerals stimulate Leydig cells to produce testosterone for the

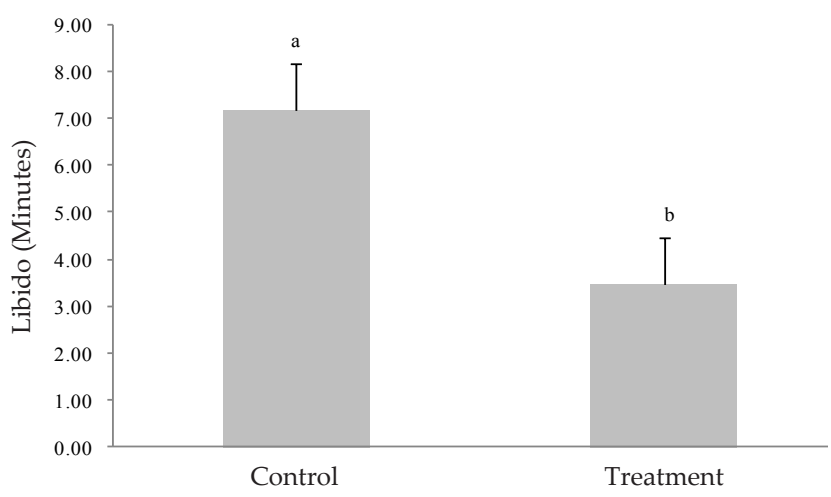

Figure 2. Libido of the Bali bulls without (control) and with (treatment) supplementation of Moringa leaves.

Table 5. Sperm concentration, motility, and characteristic sperm motility of Bali bulls without and with supplementation of Moringa leaves

\begin{tabular}{|c|c|c|c|}
\hline Variables & $\begin{array}{c}\text { Without supplementation } \\
\text { (Control) }\end{array}$ & $\begin{array}{l}\text { With supplementation } \\
\text { (Treatment) }\end{array}$ & References \\
\hline Concentration (million/mL) & $791.00 \pm 96.80$ & $817.00 \pm 58.48$ & $300-2,000^{1}$ \\
\hline Total motility (\%) & $63.99 \pm 3.37^{a}$ & $84.96 \pm 3.09 \mathrm{~b}$ & $70-90^{2}$ \\
\hline Progressive motility (\%) & $52.77 \pm 1.76^{a}$ & $67.03 \pm 3.74^{\mathrm{b}}$ & $>50^{2}$ \\
\hline \multicolumn{4}{|l|}{ Characteristic motility: } \\
\hline $\operatorname{VCL}(\mu \mathrm{m} / \mathrm{s})$ & $71.78 \pm 2.07^{a}$ & $91.24 \pm 4.32^{b}$ & $121.04 \pm 18.10^{3}$ \\
\hline $\operatorname{VSL}(\mu \mathrm{m} / \mathrm{s})$ & $31.18 \pm 0.48^{\mathrm{a}}$ & $35.14 \pm 0.84^{\mathrm{b}}$ & $60.39 \pm 14.65^{3}$ \\
\hline $\operatorname{VAP}(\mu \mathrm{m} / \mathrm{s})$ & $43.10 \pm 1.05^{\mathrm{a}}$ & $51.66 \pm 1.70^{\mathrm{b}}$ & $73.19 \pm 13.42^{3}$ \\
\hline LIN (\%) & $0.44 \pm 0.01^{\mathrm{a}}$ & $0.39 \pm 0.01^{\mathrm{b}}$ & $0.49 \pm 0.06^{3}$ \\
\hline $\mathrm{ALH}(\mu \mathrm{m})$ & $5.47 \pm 0.12^{\mathrm{a}}$ & $6.23 \pm 0.20^{b}$ & $4.19 \pm 0.52^{3}$ \\
\hline $\mathrm{BCF}(\mathrm{Hz})$ & $19.37 \pm 0.25$ & $19.70 \pm 0.28$ & $30.24 \pm 5.54^{3}$ \\
\hline
\end{tabular}

Note: Means in the same row with different superscripts differ significantly $(\mathrm{P}<0.05)$. References: ${ }^{1}$ Setchell $(2014)$, ${ }^{2}$ Susilawati $(2011)$, and ${ }^{3}$ Sarastina $e t$ al. (2012). 
normal function of the hypothalamus-pituitary-testes axis. The lack of $\mathrm{Zn}$ causes the damage of LH receptor mechanisms in controlling, storaging, and releasing of testosterone. Kumar et al. (2006) showed that Zn supplementation significantly increased serum testosterone in crossbreed cattle (Bos indicus $\times$ Bos taurus) bulls. A similar results were reported by Roy et al. (2013) in cattle, buffalo, and rabbit. Therefore, the high $\mathrm{Zn}$ level in Moringa leaf used in this study was considered to be one of the possibilities that affected the higher level of testosterone during the supplementation with the Moringa leaves. This condition is also supported by the results reported by Kumar et al. (2006) that Zn is an important component of proteins involved in the synthesis and secretion of testosterone. The results of this study indicated that supplementation of Moringa leaves significantly increased the consumption of crude protein, so that high protein content in Moringa leaves can also be suspected to trigger the synthesis process and secretion of testosterone during the treatment period.

Libido (time needed for ejaculation) of Bali bulls during the supplementation of Moringa leaf was shorter compared to that in the control i.e., 3.49 vs $7.20 \mathrm{~min}$. Average libido of Bali bulls is $4.5 \mathrm{~min}$ (Susilawati, 2011). Since libido is affected by testosterone levels (Prabsattroo et al., 2012 and Roy et al., 2013), the increased libido of experimental Bali bulls supplemented with Moringa leaves in this study was due to the elevated levels of testosterone. Therefore, the supplementation of Moringa leaves in the ration of bull could increase the level of testosterone and then increased the libido.

The results of this study indicated that supplementation of Moringa leaf could maintain sperm concentration of Bali bulls under a normal level. The sperm concentration found in this study was similar to that reported in the same breed of bulls by Susilawati (2011) and Setchell (2014). The failure of Moringa oleifera to increase the sperm concentration reported in this study was in contrary to that reported in mice by Priyadarshani \& Varma (2014) and in rats by Prabsattroo et al. (2015). They found that in hyperglycaemic mice and stressed rats, the supplementation of Moringa leaves significantly increased sperm concentration. This discrepancy might be due to the level of intake of Moringa leaves compared to body weight.

The supplementation of Moringa leaves in this study increased the total and progressive motilities of sperm in the Bali bulls. The total and progressive motilities of the sperm in this study was similar to those reported for the same breed of bulls at Singosari Artificial Insemination Center (BBIB) i.e., $83.46 \pm 4.27 \%$ and $70.68 \pm 8.92 \%$ (Sarastina et al., 2012). Study of Eghbali et al. (2010) showed that the total Ca content of seminal plasma of the buffalo is highly correlated with the total and progressive motilities of the sperm. Princewill et al. (2015) suggested that P is necessary for sperm motility. The phosphorus concentration detected in the seminal plasma of active bulls was positively correlated with both quantity and quality parameters of bovine semen. The results of this study indicated that supplementation of Moringa leaves significantly increased $\mathrm{Ca}$ and $\mathrm{P}$ consumption, so that high $\mathrm{Ca}$ and $\mathrm{P}$ content in Moringa leaf can be suspected as the cause of increased sperm motility during the period of Moringa leaves supplementation. In addition, study of Begum et al. (2009) showed that some nutrients that contribute to sperm motility were arginine, carnitine, Zn, vitamin B12, vitamin C, vitamin E, glutathione, selenium, and Coenzyme Q-10. The nutrients found in Moringa leaf are arginine, $\mathrm{Zn}$, Se, vitamin C, and E. Since Moringa leaf contains amino acid arginine (1.78\%), Zn (31.03 mg/kg), Se (363 $\mathrm{mg} / \mathrm{kg}$ ) (Moyo et al., 2011), vitamin C (220 mg/100g) (Dhakar et al., 2011), and vitamin E (77 mg/100 g) (Moyo et al., 2011), the higher sperm motility in bulls fed with Moringa leaves might be due to these nutritional contents. Further studies are needed to clarify the main nutrients that significantly affect the sperm motility.

The supplementation of Moringa leaves increased velocity (VCL, VSL, and VAP) and amplitude (ALH), but decreased linearity (LIN) of sperm in Bali bulls. Nevertheless, the values obtained are still lower than those found in Bali bulls in BBIB Singosari, probably because the bulls in BBIB Singosari are superior and selected bulls and the bulls are fed with quality feed. According to Susilawati (2011), there are 3 patterns of sperm motility, namely hyperactivate, non-hyperactivate, and transition groups. Fertility rates in the hyperactivate group had a higher success compared to the non-hyperactivated group. The requirements for hyperactivate are VCL values $\geq 100 \mu \mathrm{m} / \mathrm{s}$, LIN $<60 \%$, and ALH $\geq 5 \mu \mathrm{m}$. The observed sperm has not been included in the hyperactive category, but is approaching hyperactivate, because the VCL value is only $91.24 \mu \mathrm{m} / \mathrm{s}$.

The characteristics of sperm motility were positively correlated with fertility (Perumal at al., 2014), so it can be used to predict the fertilization capacity of the sperm. VAP, VSL, and LIN values are progressive motility indicators and VCL, ALH, and BCF values are indicators of sperm rigor. VAP and VCL values are a good predictor of the ability of sperm to fertilize in vitro (Susilawati, 2011). The values of these parameters at the treatment period were higher than during pretreatment or control period, thus having the possibility of producing more fertile sperm.

\section{CONCLUSION}

The supplementation of $15 \%$ Moringa leaves in the concentrate ( $1 \%$ of body weight) markedly increased plasma testosterone concentrations, libido, and sperm motility of Bali bulls.

\section{ACKNOWLEDGMENT}

The authors would like to thank Ministry of Research, Technology and Higher Education, Indonesia for Postgraduate Scholarship (BPPDN) and supporting this research through PENELITIAN DISERTASI DOKTOR with research agreement No. 070/SP2H/LT/ DRPM/IV/2017 date May 4, 2017. The authors also to thank Samata Integrated Cultivation System, Gowa District, South Sulawesi which has provided the pens and experimental bulls, assisted the collection of semen, and blood sampling. 


\section{REFERENCES}

Abu, A. H., T. Ahemen \& P. Ikpechukwu. 2013. The testicular morphometry and sperm quality of rabbit bucks fed graded levels of Moringa oleifera leaf meal (MOLM). Agrosearch 13:49-56. https://doi.org/10.4314/agrosh.v13i1.5

Begum H., A. Moniruddin, \& K. Nahar. 2009. Environmental and nutritional aspect in male infertility. J. Medicine 10:1619. https://doi.org/10.3329/jom.v10i1.1997

Bhakat, M., T. K. Mohanty, V. S. Raina, A. K. Gupta, H. M. Khan, R. K. Mahapatra, \& M. Sarkar. 2011. Effect of age and season on semen quality parameters in Sahiwal bulls. Trop. Anim. Health. Prod. 43:1161-1168. https://doi. org/10.1007/s11250-011-9817-1

Chauhan, N. S., V. Sharma, V. K. Dixit, \& M. Thakur. 2014. A review on plants used for improvement of sexual performance and virility. BioMed. Res. Int. 2014 Article ID 868062, 19 pages. https://doi.org/10.1155/2014/868062

Cheah, Y. \& W. Yang. 2011. Functions of essential nutrition for high-quality spermatogenesis. Adv. Biosci. Biotechnol. 2:182-197. https://doi.org/10.4236/abb.2011.24029

Dafaalla, M.M., A. W. Hassan, O. F. Idris, S. Abdoun, G. A. Modawe \& A. S. Kabbashi. 2016. Effect of ethanol extract of Moringa oleifera leaves on fertility hormone and sperm quality of Male albino rats. World J. Pharm. Res. 5:1-11.

Dhakar, R. C., S. D. Maurya, B. K. Pooniya, N. Bairwa, M. Gupta, \& Sanwarma. 2011. Moringa: The herbal gold to combat malnutrition. Chron Young Sci. 2: 119-125. https:// doi.org/10.4103/2229-5186.90887

DRG International, Inc., USA. 2009. DRG ${ }^{\circledR}$ Testosterone ELISA (EIA-1559). www.drg-international.com/ifu/eia-1559.pdf (10 June 2016).

Eghbali, M., S. M. Alavi-Shoushtari, S. Asri-Rezaei, \& M. H. K. Ansari. 2010. Calcium, magnesium and Total Antioxidant Capacity (TAC) in seminal plasma of Water Buffalo (Bubalus bubalis) bulls and their relationships with semen characteristics. Vet. Res. Forum 1:12-20.

Ferreira, P. M. P., D. F. Farias, J. T. A. Oliveira \& A. F. U. Carvalho. 2008. Moringa oleifera: Bioactive compounds and nutritional potential. Rev. Nutr. 21 Campinas:431-437. http://dx.doi.org/10.1590/S1415-52732008000400007.

Fitri, A., T. Toharmat, D. A. Astuti, \& H. Tamura. 2015. The potential use of secondary metabolites in Moringa oleifera as an antioxidant source. Med. Pet. 38:169-175. https://doi. org/10.5398/medpet.2015.38.3.169

Kastelic, J. P. 2013. Male involvement in fertility and factors affecting semen quality in bulls. Animal Frontiers. 3: 20-25. https://doi.org/10.2527/af.2013-0029

Kumar, N., R. P. Verma, L. P. Singh, V. P. Varshney, \& R. S. Dass. 2006. Effect of different levels and sources of zinc supplementation on quantitative and qualitative semen attributes and serum testosterone level in crossbred cattle (Bos indicus $\times$ Bos taurus) bulls. Reprod. Nutr. Dev. 46:663675. https://doi.org/10.1051/rnd:2006041

Lemma. A. \& T. Shemsu. 2015. Effect of age and breed on semen quality and breeding soundness evaluation of preservice young bulls. J. Reprod. Infertil. 6: 35-40.

Madukwe, E. U., J. O. Ezeugwu, \& P. E. Eme. 2013. Nutrient composition and sensory evaluation of dry Moringa oleifera aqueous extract. Int. J. Sci. Basic Appl. Res. 13: 100-102.

Martin, G. B., D. Blache, D. W. Miller, \&. E. Vercoe. 2010. Interactions between nutrition and reproduction in the management of the mature male ruminant. Animal 4:1214-1226. https://doi.org/10.1017/S1751731109991674

Menegassi, S. R. O., J. O. J. Barcellos, V. Peripolli, \& C. M. Camargo. 2011. Behavioral assessment during breeding soundness evaluation of beef bulls in Rio Grande do Sul. Anim. Reprod. 8:77-80.
Moyo, B., P. J. Masika, A. Hugo, \& V. Muchenje. 2011. Nutritional characterization of Moringa (Moringa oleifera Lam.) Leaves. Afr. J. Biotechnol. 10:12925-12933. https:// doi.org/10.5897/AJB10.1599

Nouman, W., M. T. Siddiqui, S. M. A. Basra, H. Farooq, M. Zubair, \& T. Gull. 2013. Biomass production and nutritional quality of Moringa oleifera as a field crop. Turk. J. Agric. For. 37: 410-419. https://doi.org/10.3906/tar-1206-29

Nouman, W., S. M. A. Basra, M. T. Siddiqui, A. Yasmeen, T. Gull, \& M. A. C. Alcayde. 2014. Potential of Moringa oleifera L. as livestock fodder crop: a review. Turk. J. Agric. For. 38:1-14. https://doi.org/10.3906/tar-1211-66

Nutrient Requirements of Beef Cattle. 2000. Seventh Revised Edition: Update Subcommittee on Beef Cattle Nutrition, Committee on Animal Nutrition, National Research Council. Available from the National Academies Press at: http://www.nap.edu/catalog/9791.html.

Perumal, P., S. K. Srivastava, S. K. Ghosh, \& K. K. Baruah. 2014. Computer-assisted sperm analysis of freezable and nonfreezable Mithun (Bos frontalis) semen. Journal of Animals 2014:Article ID 675031, 6 pages.

Prabsattroo, T., J. Wattanathorn, S. Iamsaard, S. Muchimapura, \& W. Thukhammee. 2012. Moringa oleifera leaves extract attenuates male sexual dysfunction. Am. J. Neurosci. 3:1724. https://doi.org/10.3844/amjnsp.2012.17.24

Prabsattroo, T., J. Wattanathorn, S. Iamsaard, P. Somsapt, O. Sritragool, W. Thukhummee, \& S. Muchimapura. 2015. Moringa oleifera extract enhances sexual performance in stressed rats. J. Zhejiang Univ. Sci. B 16:179-190. https:// doi.org/10.1631/jzus.B1400197

Princewill, O. I., A. E. Uchenna, O. I. Charles, \& I. M. Uwaezuoke. 2015. Interactions between dietary minerals and reproduction in farm Animal. Global Journal of Animal Scientific Research 3:524-535.

Priyadarshani, N \& M. C.Varma. 2014. Effect of Moringa oleifera leaf powder on sperm count, histology of testis and epididymis of hyperglycaemic mice Mus musculus. Am. Int. J. Res. Form. Appl. Nat. Sci. 7:07-13.

Rajanandh, M. G. \& J. Kavitha. 2010. Quantitative estimation of $\beta$-sitosterol, total phenolic and flavonoid compound in the leaves of Moringa oleifera. Int. J. Pharmtech. Res. 2:1409-1414.

Raji, A. Y. \& A. A. Njidda. 2014. Gonadal and extra-gonadal sperm reserves of the Red Sokoto goats fed Moringa oleifera supplemented diets. Inter. J. Agri. Biosci. 3:61-64.

Roy, B., R. P. S. Baghel, T. K. Mohanty, \& G. Mondal. 2013. Zinc and male reproduction in domestic animals: A Review. Indian J. Anim. Nutr. 30:339-350.

Sarastina, T. Susilawati, \& G. Ciptadi. 2012. Analysis of sperm motility parameters in various breed bulls using a computer-assisted semen analysis (CASA) (In Indonesian). J. Ternak Tropika 6:1-12.

Setchell, B. P. 2014. Semen and its Constituents. In: Chenoweth P. J. \& S. P. Lorton (Eds). Animal Andrology: Theories and Applications. CAB International, Boston, USA. p.3-11. https://doi.org/10.1079/9781780643168.0003

Susilawati, T. 2011. Spermatologi (In Indonesian). Universitas Brawijaya Press (UB Press), Malang.

Wu, G., F. W. Bazer, T. A. Davis, S. W. Kim, P. Li, J. M. Rhoads, M. C. Satterfield, S. B. Smith, T. E. Spencer, \& Y. Yin. 2009. Arginine metabolism and nutrition in growth, health, and disease. Amino Acids 37:153-168. https://doi.org/10.1007/ s00726-008-0210-y

Young, S. S., B. Eskenazi, F. M. Marchetti, G. Block, \& A. J. Wyrobek. 2008. The association of folate, zinc and antioxidant intake with sperm aneuploidy in healthy nonsmoking men. Hum. Reprod. 23:1014-1022. https://doi. org/10.1093/humrep/den036 